\title{
Geology in Great Britain
}

$\mathrm{P}$ ART I of the "Summary of Progress of the Geological Survey of Great Britain" for $1931^{1}$ contains the usual annual reports of the Geological Survey Board and of the Director and gives particulars of routine work carried out during the year under review. Fifty-four maps were issued, together with four English and two Scottish memoirs, all of which have already been noticed in our columns (Nature, $131,370-372 ; 1933$ ). Part $2^{2}$ contains a series of papers on subjects of special interest. The Carboniferous system receives particular attention, D. A. Wray dealing with the Yorkshire Coal Measures and S. W. Hester with the Millstone Grits of North Staffordshire, while Stanley Smith, R. Crookall and W. S. Bisat discuss palæontological problems. C. B. Wedd contributes notes on the Ordovician of Montgomeryshire and an important study of Palæozoic and later tectonic structures between the Longmynd and the Berwyns. Three new species of Old Red Sandstone fishes are described by D. M. S. Watson. Petrology is represented by two highly interesting papers : one by Sir John Flett on the Stankards Sill, a teschenite-picrite intrusion in which differentiation was accomplished either before or during intrusion; the other by A. G. MacGregor and W. Q. Kennedy on the Morvern-Strontian 'granite', a complex of the appinite-lamprophyre suite followed by tonalites, granodiorites and biotite-granite.

Part I of the "Summary" for $1932^{3}$, in addition to the usual information, records the plans for displaying exhibits in the New Museum of Practical Geology at South Kensington, plans that are now being actively put into operation. New models have been constructed to show the relation of geological structure to surface features in several characteristic British regions, and panoramic displays designed to illustrate geological processes and mining geology. Maps issued in 1932 numbered 59 and there were published five English and three Seottish memoirs some of which have been noticed already (loc. cit.) while others, together with some that have since appeared, are briefly reviewed below.

In Part $2^{4}$ Sir John Flett describes the important changes in the interpretation of the geology of Meneage rendered necessary by critical discoveries made in recent years. Three important contributions to the geology of the Kent Coalfield are made by H. G. Dines (sequence and structure), R. Crookall (fossil flora) and C. J. Stubblefield (fossil fauna). Other palæontological papers are by Gertrude L. Elles on the Lower Ordovician graptolites with special reference to the Skiddaw Slates and by S. H. Straw on a Palæozoic fauna revealed by the Little Missenden boring; Sir Arthur Smith Woodward reports on the fish remains of this fauna. E. E. L. Dixon describes the Gault of Cambridgeshire. An example of composite auto-intrusion in a Lower Carboniferous lava-flow (mugearite and trachyandesite) provides W. Q. Kennedy with a petrological problem of a new type.

The memoir on the Cheviot Hills ${ }^{5}$ (Sheets 3 and 5 ) replaces two smaller ones issued in 1888 and 1895 , and deals with an area of special interest since it includes a deeply dissected volcano of old Red Sandstone age, laid open by long exposure to erosion. Violent eruptions broke through a land-area of intensely folded Silurian sediments and these were followed by the outpouring of andesitic lavas. After a pause, activity was resumed with the intrusion of granite. The rock is normally a pink granophyric type, but varieties produced by the absorption of earlier and more basic rocks are not uncommon. There was much tourmalinisation towards the north and west, and ramifying strings of felsite were injected as the granite consolidated. Two wellmarked dyke-swarms followed, this final episode also closing with felsitic veins. After long denudation, Carboniferous rocks overlapped against the Cheviots and with them was associated a renewal of volcanic activity. Later igneous action is represented by lateCarboniferous dykes and by the Acklington dyke of Tertiary age. The Jurassic and Cretaceous periods have left no trace. The glaciology of the region, rich in phenomena connected with the retreat of the last great ice-sheet, receives full treatment.

Under the general title of "Economic Geology of the Ayrshire Coalfields" a series of four memoirs has now been issued. The first two dealt with north Ayrshire and appeared in 1925. The third is devoted to the Mauchline Basin and the coalfields to the west and east, and was published in 1930. The present volume $^{6}$ is the last of the series and is concerned with the southern portion of the field, which includes the Carboniferous Limestone Coals of Dailly and Patna and the important seams in the Coal Measures of Dalmellington and New Cumnock. Extensive out. crops of Ordovician, Silurian and Old Red Sandstone rocks border the area everywhere save along the northern margin. The Calciferous Sandstone, Carboniferous Limestone, and Coal Measure Series follow in upward succession. Preliminary correlations of the Coal Measures by means of 'mussel' zones are made with the English equivalents. A striking feature is the series of powerful faults crossing the country in a north-east direction, probably determined by the strike of the axes of the compressed folds in the older Palæozoic rocks that underlie the district. Igneous activity is represented by Permian sills, dykes and vents and by Tertiary dykes.

The Central Coalfield of Scotland has been divided. into nine areas, to each of which a separate memoir has been assigned. Area $\mathrm{III}^{7}$, dealing with the country around Bo'ness and Linlithgow, is the eighth in order of issue, and the series will be completed by the memoir on Area I now in preparation. The region now described drains entirely to the Firth of Forth. Calciferous Sandstone sediments occur in the south-east and are followed in regular succession to the west by the Carboniferous Limestone Series (including the Limestone Coal Group), the Millstone Grit, and the Productive Coal Measures. The main complications as regards structure arise from the great thicknesses of volcanic rocks that occur locally, most of these falling within the limits of the Carboniferous Limestone. Sills, dykes and vents represent related intrusions, the later quartz-dolerites being assigned to a Permo-Carboniferous age. Mining of coal from the Limestone Coal Group has been carried on in the Bo'ness field for several centuries, and the landward coal is now nearly exhausted. Special sections deal with recent mining developments underneath the Forth and with the concealed coalfield below the Millstone Grit and Coal Measures to the west. Glaciation and the superficial deposits receive detailed attention and also such economic 
materials as building stone, fireclay, limestone and road metal.

Leaving the north, we turn to a memoir ${ }^{8}$ describing the country to the south and south-east of Cambridge (Sheet 205), a district almost wholly devoted to agriculture and most of it but thinly inhabited. The solid rocks exposed are of Cretaceous age, from the Gault to the Upper Chalk, but the Lower Greensand, which yields good supplies of water, has been reached in many well-borings in the north-west. The greater part of the memoir deals with the Pleistocene and other superficial drifts. In addition to glacial gravels and boulder clays and fluviatile terrace gravels and alluvium, a series of deposits termed 'Taele Gravels' is distinguished. The word 'Taele' is used in Denmark and Norway to signify deeply frozen ground, and by the melting of this, coupled with heavy precipitation, the mud-flows and washed and bedded gravels of these deposits have probably been formed. The glacial history is of great complexity and as final conclusions cannot as yet be reached, the alternative views are fairly presented. Records of several new wells are included and contoured maps are given showing the water-table in the Chalk in 1928 and 1929.

The memoir describing the well-known country around Reigate and Dorking' ${ }^{9}$ (Sheet 286) is likely to make a wide appeal since it extends from Epsom across the North Downs to Leith Hill and is a picturesque and favourite residential district within easy reach of London. The geological structures epitomise those found throughout the Wealden area. Though the regional dip corresponds to the gentle flexure of the Weald dome, the structure is locally complicated by subsidiary folds, generally monoclinal, in which steeper dips, sometimes nearly vertical, occur. Details of these are clearly described. The solid formations range from the Lower Cretaceous Tunbridge Wells Sand to the Eocene Bracklesham Beds, and due attention is given to the scanty Pliocene remains and to the Pleistocene and Recent superficial deposits. Economic aspects are dealt with somewhat fully, especially water supply and fullers' earth. The latter, as prepared at Nutfield, excels in quality to such a degree that it forms a standard by which other varieties are gauged. A noteworthy chapter is devoted to the scenery and drainage systems of this attractive countryside.

The Cirencester memoir ${ }^{10}$ is descriptive of Sheet 235 and is a notable contribution to the geology and geography of the Coteswolds by an author distinguished for his researches on these classic hills. Apart from the superficial deposits, which do not make extensive spreads, the formations are wholly Jurassic, ranging from the Lower Lias to the Oxford Clay. Just off the map the Palæozoic floor was reached in a boring near Burford Signet. A valuable part of the memoir is that on agriculture by Prof. J. A. Hanley. Not only is this a contribution of interest to agriculturists and soil investigators, but also to botanists, since it contains many references to the connexion between the flora and the parent rocks. Questions of water supply are discussed but briefly, as this topic has already received detailed treatment in the "Wells and Springs of Gloucestershire" issued by the Survey in 1930 .

The memoir on the Holmfirth and Glossop district ${ }^{11}$ (Sheet 86 ) covers part of the high moorland (north of the Derbyshire Dome) of the Southern Pennines, everywhere formed by the Millstone Grits, and the adjoining portions of the coalfields of Yorkshire and
Lancashire-Cheshire. Full use has been made of recent advances in our knowledge of the palæontology of the Millstone Grits and, as a result, the structure of the area has been worked out in great detail. It is of interest to find that the structural disturbance which divides the Yorkshire Coalfield into two parts, the West and South Yorkshire fields respectively, can be traced far back into Millstone Grit times. The beds thicken both north and south from the neighbourhood of Hepworth and Denby Dale, showing that movement was taking place contemporaneously with their deposition. Much new information is also given of the non-marine lamellibranchs of the Coal Measures. During Glacial times, this part of the Pennines lay between the great ice sheets of the east and west and was practically unglaciated, and in consequence it is a region of special interest to botanists and archæologists.

The Torquay memoir ${ }^{12}$, which is a second edition, revised after thirty years, embraces such well-known South Devon localities as Paignton, Totnes and Dartmouth, as well as Torquay itself (Sheet 350). The area includes a diversified stretch of picturesque coastline, famous for its fine sections of Devonian and New Red rocks, and many of these are effectively illustrated by photographs and line-drawings. The general correlation of the sub-divisions of the Devonian with those of the Continent may now be regarded as established, correspondence with the German type being closer than with the FrancoBelgian type. Igneous rocks have a wide distribution, particularly in the Ashprington district. Spilitic lavas are common and most of the intrusions are albitised dolerite; quartz-keratophyres occur, but are relatively infrequent and have their chief development in the Lower Devonian. Pleistocene phenomena are well represented by bone caverns, including the famous Kent's Cavern, raised beaches, and the submerged forest bordering the shores of Tor Bay. Notable new features are the petrology of the igneous rocks, the palæontology of the Lower Devonian and the treatment of the soils and agriculture of the area. This memoir, like some of the others described above, should be of special value to students and others taking part in geological excursions.

1 "Summary of Progress of the Geological Survey of Great Britain and the Museum of Practical Geology for the Year 1931." Part 1. Pp. iv +81 . 1s. $6 d$. net.

2 Ibid. Part 2. Pp. vi $+166+4$ plates. 3s. net.

${ }^{3}$ Ibid. for the year 1932 . Part 1 . Pp. iv +98. 2s, net.

${ }^{4}$ Ibid. Part 2 . Pp. iv $+142+10$ plates. 3s, net.

s "The Geology of the Cheviot Hills". By R. G. Carruthers, G. A. Burnett and $W$. Anderson, with Petrological Notes by $H$. H. Thomas. Pp. $\mathrm{xi}+174+7$ plates. $4 s$. net.

" "Economic Geology of the Ayrshire Coalfields, Area IV (Dailly, Patna, Rankinston, Dalmellington and New Cumnock)." . By J. B, Simpson and A. G. MacGregor, with contributions from J. E. Richey and V. A. Eyles. Pp. viii $+167+3$ plates. 3s. 6d. net.

7 "Economic Geology of the Central Coalfield, Area III (Bo'ness and Linlithgow)." By M. Macgregor and D. Haldane. Pp. vi $+128+$ 1 plate. $3 s$. net.

8 "The Geology of the Country near Saffron Walden". By H. J Osborne White, with contributions by F. H. Edmunds. Pp. xii $+126+$
H. The Geology of the Country near Saffron Walden". 5 plates. $3 s$. net.

"The Geology of the Country around Reigate and Dorking". By H. G. Dines and F. H. Edmunds, with notes by H. Dewey and C. J. Stubblefield, and a chapter on palæontology by C. P. Chatwin. Pp. vii $+194+5$ plates. $4 s$. net.

10 "The Country around Cirencester." By Linsdall Richardson, with contributions by J. A. Hanley and H. G. Dines. Pp. xi+119+7 plates. 38 . net.

" "The Geology of the Country around Holmfirth and Glossop." By C. E, N. Bromehead, Wilfrid Edwards, D, A. Wray and J. Y. Stephens, with notes by G. V. Wilson and W. Lloyd. Pp. xii $+194+$ 5 plates. 48 . net.

12 "The Geology of the Country around Torquay." By W. A. E. Ussher. Second edition (revised). By W. Lloyd, with palreontology by C. P. Chatwin, and a chapter on the petrography of the Igneous. Rocks by W. G. Shannon. Pp. xiii $+169+7$ plates. 48 . net.

London: H.M. Stationery Office, 1932-34. 